\title{
Picturing translocal youth: self-portraits of young Syrian refugees and young people of diverse African heritages in South-East England
}

Article

Accepted Version

Evans, R. (2020) Picturing translocal youth: self-portraits of young Syrian refugees and young people of diverse African heritages in South-East England. Population Space and Place, 26 (6). ISSN 1544-8444 doi: https://doi.org/10.1002/psp.2303 Available at https://centaur.reading.ac.uk/87771/

It is advisable to refer to the publisher's version if you intend to cite from the work. See Guidance on citing.

To link to this article DOI: http://dx.doi.org/10.1002/psp.2303

Publisher: Wiley

All outputs in CentAUR are protected by Intellectual Property Rights law, including copyright law. Copyright and IPR is retained by the creators or other copyright holders. Terms and conditions for use of this material are defined in the End User Agreement. 


\section{CentAUR}

Central Archive at the University of Reading

Reading's research outputs online 
Title page for paper submitted to Population, Space and Place

Special Issue on Transnational Youth Mobilities

\author{
Author: Ruth Evans, Associate Professor in Human Geography, Department of \\ Geography \& Environmental Science, University of Reading
}

Title of paper: Picturing translocal youth: self-portraits of young Syrian refugees and young people of diverse African heritages in South-East England

\begin{abstract}
(150 words)
Young refugees and diasporic youth often have multiply-located senses of self. Using a creative visual methodology, recently arrived young Syrian refugees and young people of diverse African heritages born in the UK (aged 16-20) produced digital self-portraits to express their translocal subjectivities. Young Syrians represented themselves as 'bilingual becomings'; learning English occupied their minds and was key to their imagined futures, while their hearts were often associated with the homeland they had lost. In contrast, speaking English was sometimes taken for granted in the art work produced by young people of African heritages, which portrayed hybrid, multilingual selves and translocal relationality. Both groups embraced signifiers of national, religious and cultural identity, but through their silences and omissions, dis-identified with exclusionary notions of 'Britishness', nationhood and citizenship. Their self-representations provide hopeful counter-narratives to hegemonic socio-political discourses that position 'Black African' youth and Muslim young men as a 'threat' and 'illegitimate' citizens.
\end{abstract}




\section{Key words}

Translocal subjectivities

Embodied relationality

Mobile youth transitions

Creative visual methods

Linguistic repertoires

Young refugees

\section{Contact details:}

Dr. Ruth Evans

Associate Professor in Human Geography

Department of Geography \& Environmental Science

University of Reading

Whiteknights PO Box 227

Reading RG6 6AB, UK

Email: r.evans@reading.ac.uk 


\section{Picturing translocal youth: self-portraits of young Syrian refugees and young people of diverse African heritages in South-East England}

\section{Introduction}

Young refugees are not only 'on the move' (Boccagni \& Baldassar, 2015) in terms of their mobility across borders. They are also engaged in crucial 'boundary crossings' during the liminal phase of youth (Robertson, Harris, \& Baldassar, 2017). Such mobilities encompass socially expected youth transitions in affluent societies (moving from school to further education college, apprenticeships and/or university and into employment, moving out of the parental home, cohabitation/ marriage, childbirth and so on), as well as less tangible transitions. These may include further developing their social identities and relationships, engaging with youth sub-cultures, identifying with or subverting cultural norms and gendered, familial expectations and establishing place-attachments and a sense of belonging to particular communities (Valentine \& Skelton, 2005; Robertson et al, 2017).

Given the multiply-located senses of self and belonging that migrants often experience in settlement countries (Conradson \& McKay, 2007), such youth transitions may be particularly challenging for young refugees and youth from diaspora communities. As Robertson et al (2017, p.209) observe, “Transition conditions may be 'stretched' across borders or normative transition pathways may be transformed by mobility - resisted, disrupted or redirected through delays, accelerations or protractions". Translocal youth mobilities and transitions are thus characterised by complex temporalities and contradictory timelines (Clayton, 2019, p.123), from past experiences 'there', to their present lives 'here', and imagined futures. 
Further, the identities and everyday lives of transnational youth may be characterised by extensive mobilities and translocal emotional connections to relatives and friends across the globe. Processes of identification and dis-identification with the cultural values of a 'homeland' and with often highly politicised, racialized discourses of nationhood, citizenship and migration may vary among different diaspora groups and between generations (Valentine \& Sporton, 2009; Ní Laoire et al, 2010; Evans, 2011; Waite and Cook, 2012). Diasporic youth mobilities and the multiple place attachments and citizenships of 'first' and 'second generation' migrants, particularly Muslims, have become increasingly positioned as a 'security threat' in the UK and other affluent settlement countries (Antonsich, 2016; Clayton, 2019; Robertson et al, 2017).

This paper explores how two diverging groups of 'transnational youth' - recently arrived young Syrian refugees and young people of diverse African heritages born in the UK express their translocal subjectivities and embodied relationality within a broader sociopolitical landscape which may restrict their agency. In the UK, this landscape includes continuing legacies of British imperialism, 'superdiverse' city spaces, increasingly hostile immigration policies, populist political and media discourses, race hate crime and far-right extremism, which exacerbate intersecting inequalities based on gender, race and religion (Hopkins, 2007; 2016; Jones, Gunaratnam, Dhaliwal et al., 2017; Nayak, 2017). The economic climate of austerity has also had a major impact on third sector refugee and diaspora organisations, English language education and other public services in the UK (Mayblin \& James, 2018).

Given this context, it seems ever more important to provide space for the expression of young people's own counter-narratives and self-representations of their translocal subjectivities and Syrian refugees and young people of diverse African heritages in South-East England, Population, Space \& Place. 
sense of belonging (Clayton, 2019). By linking young people's agency in constructing their identities to wider socio-political discourses and institutional environments, I seek to respond to Ansell (2009)'s call for 'descaled' geographies of youth. The research focus on recently arrived young Syrian refugees and 'second generation' young people of African heritage also responds to Robertson et al's $(2017, \mathrm{p} .210)$ call for comparative or 'contrapuntal' analysis that looks at divergent types of youth mobility within the same study. Using a creative, visual methodology, I adopt an intersectional lens and analyse young people's embodied representations of selfhood in relation to hegemonic discourses and signifiers of nationhood, citizenship and migration. As recent commentators have observed, despite the rapid pace of globalisation and movement across borders, the national dimension still plays an important role in young people's political geographies (Hopkins and Alexander, 2010; Nayak, 2017) and the securitisation of migration (Antonsich, 2016).

In this paper, I first discuss the theoretical framing used to interpret young people's selfportraits and emotional connections across space, drawing on the concepts of translocal subjectivities, intersectionality and embodied linguistic repertoires. I then give an overview of the youth-focused creative visual methodology adopted. The empirical sections discuss the socio-spatial dynamics of young people's self-portraits, exploring first Syrian young men's self-representations as bilingual 'becomings', focused on their imagined futures in the host country through English language learning; and secondly, the hybrid, multilingual selves portrayed by young people of diverse African heritages growing up in multi-ethnic London. The contrapuntal analysis brings the two groups' art work into dialogue with each other and relates it to wider socio-political narratives, followed by a discussion of the mapping of young people's translocal relationality in London. I conclude by reflecting on the paper's 
contributions to the emerging fields of 'emotions on the move' and transnational youth mobilities (Boccagni \& Baldassar, 2015; Robertson, Harris, \& Baldassar, 2017).

\section{Theoretical framing}

My approach to interpreting young people's translocal subjectivities is informed by the growing body of work exploring the emotional geographies of migration, mobility and belonging (Boccagni \& Baldassar, 2015; Askins, 2015; Mee \& Wright, 2009), alongside recent literature on the emotional, embodied geographies of children and youth (Blazek \& Windram-Geddes, 2013; Ní Laoire et al, 2010; Nayak, 2017; Evans, 2011). I draw on Conradson \& McKay's (2007) notion of translocal subjectivities to explore young people's multiply-located senses of self, belonging and attachments to place. Translocality seeks to capture the diverse and contradictory effects of the interconnectedness between places, institutions and actors (Massey, 1994), addressing flows, networks and the circulation of ideas, symbols and knowledge (Greiner \& Sakdapolrak, 2013).

Boccagni and Baldassar (2015) observe that the different, potentially conflicting emotional orientations migrants experience stem from 'an extended process of adaptation to the expectations of the receiving society, and of selective retention of their earlier identity and emotional worlds' (p.76, original emphasis). As I discuss in relation to the visual data, the notion of '(emotional) ambivalence’ (Boccagni \& Baldassar, 2015) is particularly pertinent in understanding young people's embodied self-representations that draw on hegemonic signifiers of nationhood, citizenship and named languages. Furthermore, Nayak's (2017) analysis of multicultural encounters in the lives of British Bangladeshi Muslim young women suggests that heightened national events such as the aftermath of terrorism, the 'Brexit' result and accompanying escalation in hate crime, 'not only mark bodies out in different ways, but 
they impinge and impress on them, pushing them out of some spaces and forcing them into others' (p.299).

Linked to this understanding of translocal subjectivities and embodied representations of race, ethnicity, nationhood and belonging, I adopt an intersectional approach that seeks to understand not only multiple identities, but how relationality and the wider social context shapes the performance of embodied subjectivities (Hopkins, 2017). Intersectionality can help to 'enrich our understanding of migrants' connections with multiple places and localities' (Hopkins, 2017, p.7) and draws attention to 'the fluctuating emotional investment in different subject positions' (Valentine and Sporton, 2009, p.736). I explore the ways in which young people perform their embodied identities in relation to complex intersections of social difference, focusing in particular on gender, race, ethnicity and religion and how these inflect each other (Dwyer, 1999; Barber, 2015). I also seek to understand how young people from refugee backgrounds position themselves, and how they are positioned by others, in relation to 'mobile transitions' and hegemonic narratives of nationhood, citizenship and migration (Antonsich, 2016; Hopkins \& Alexander, 2010; Nayak, 2017; Robertson et al, 2017; Staeheli et al, 2012).

The visual methodology adopted in this research provides a window into the ways that hybrid racialized identities are constructed through visual signifiers (Rose, 2016). I draw on Busch's (2012) poststructural methodological approach to linguistic repertoires, which uses an outline of the body as a metaphor to help understand participants' biographies and feelings about communicating and using different languages in everyday life. Citing Butler (1997)'s arguments about the normativity of language which determines what is 'say-able' and what is not, Busch (2012) comments that the restrictive power of categorizations is particularly felt Syrian refugees and young people of diverse African heritages in South-East England, Population, Space \& Place. 
when language is not self-evidently available, such as when people are not recognised or do not recognise themselves as legitimate speakers of a specific language. A linguistic repertoire is thus a space both of restrictions and possibilities.

\section{Methodology}

A youth-focused creative visual methodology was considered most appropriate for this project, since it may enable young people to have greater control over the representation of their relational identities (Grant, 2015). Providing creative opportunities for selfrepresentations seems particularly salient when working with young migrants (Clayton, 2019; Sime, 2015) and young people of minority ethnicities who may be positioned as racialised 'Others' in everyday school and neighbourhood spaces as a means of 'purging the nation and exerting white territoriality' (Nayak, 2017, p.290). Participatory art workshops were held with a purposive sample of recently arrived young Syrian refugees (aged 16-20) living in Reading and young people of African heritage born in the UK and living in South London. This strand of a larger exploratory project aimed to address the following research question: How are young people's identities and sense of belonging shaped by translocal emotional connections and multilingualism?

The research adapted Busch's (2012) linguistic repertoire and Farmer and Cepin's (2017) digital technology approach to language portraits. Young people were encouraged to use digital photography and collage art software on ipads to create digital self-portraits. In workshops held in community spaces, young people helped each other to take a portrait photograph and were encouraged to consider which pose they wanted to adopt, and then to add drawing, words or special effects using collage software on their body image in order to express their embodied feelings about speaking different languages, ways of communicating 
and anything else they wanted to convey about their identity. In order to protect young people's identities when using photography, young people were asked to anonymise their self-portraits by drawing or covering their faces. They chose a title for their self-portrait and a pseudonym. Young people were encouraged to talk to the group about the image they had created and why they had chosen to include particular signs, words or colours. Their narratives about their self-portraits were audio-recorded and transcribed.

The small, purposive sample of young people who wished to participate in art workshops was identified through contacts with refugee and diaspora organisations. This comprised two groups: 5 Syrian young men (aged 16-20) who had arrived in the UK under the Humanitarian Programme for Syrian refugees with family members between three to seven months previously and who lived in Reading; and 5 young people of African heritage (four young women and 1 young man aged 16-17) who had been born in the UK and lived in London. The mothers of three participants of Zimbabwean and Congolese heritage had previously participated in an art workshop I had facilitated and had claimed asylum in the UK and been granted refugee status, prior to becoming British citizens, while I had not met the parents of the young women of Somali heritage, who had engaged in secondary migration to the UK from Italy.

The workshop with Syrian young men in Reading was conducted in English and Arabic, with translation into and from Arabic provided by a research assistant who was familiar to the young men from her volunteer work with the local refugee organisation and was seeking asylum herself. She also translated and transcribed into English the audio-recorded narratives about young people's images and the discussion which followed about young people's experiences of learning English and their aspirations for the future. The group of five young Syrian refugees and young people of diverse African heritages in South-East England, Population, Space \& Place. 
men included two pairs of brothers. The workshop with young people of African heritages in London was conducted in English with seven participants from four families; two participants were brother and sister and two younger siblings (aged 6 and 8) accompanied one of the older young people, but their images and diagrams have not been included in the analysis for this paper.

A participatory mapping exercise about young people's personal communities and translocal emotional connections was also facilitated with young people in the longer art workshop in London. This was a two-stage process, the first of which was based on the method of personal community mapping (Spencer \& Pahl, 2006). Young people were asked to write the names of members of their family, friends or neighbours on sticky notes and position them on their map of three concentric circles, depending on how close they felt to them. They shared with the group their personal communities and why people were important to them, which was audio-recorded and transcribed. In the second stage, young people produced together a large mural-sized world map, painting with different colours all the countries with which they felt a connection, on a prepared outline of a world map. They then painted all the other countries in one colour (orange). Young people then wrote something about their emotional connections and caring relationships on a label which they attached to a thread stuck on the map, linking London to the different places globally with which they felt emotional connections (see Figures 10 and 11).

My 'reading' of the young people's self-portraits and the collective map of translocal connections is based on interpreting their narratives of the images produced, their title and pseudonym, in addition to analysing socio-spatial dynamics involved in the construction of the image and the wider social context. When engaging in a socio-spatial analytical process Syrian refugees and young people of diverse African heritages in South-East England, Population, Space \& Place. 
of 'seeing' gendered bodies in photographs, Breckner (2007, p. 129) comments that researchers can focus on several aspects, including: the producer's imagination (and possibly their prior experience); thematic issues such as those manifested in the concrete as well as symbolic order of objects; iconic realities which are constituted by light, lines, colours, contrasts, perspectives, constellations; moments of interaction, which refer to a reality that goes beyond what is captured in the picture; absent realities, which the pictures points at, and without which the picture would not be comprehensible; contexts in which a picture was made, saved and used; and the interrelation of all these aspects.

This small, exploratory study does not aim to be representative of the experiences of young Syrian refugees or young people of African heritages. The young people's self-portraits and narratives do however provide qualitative, visual insights into the socio-cultural construction of youth identities and translocal emotions in relation to wider socio-political discourses. The perspectives of the two groups of young people, with very different temporal proximities to the migration process, provide an interesting comparison and point of departure for future research on transnational youth mobilities (Robertson et al, 2017).

\section{Findings}

\section{Bilingual 'becomings'}

The self-portraits created by recently arrived Syrian young men in Reading attributed considerable importance to the English language and representations of the British nationstate. Three of the Syrian young men drew the Union Jack on their heads in order to symbolise learning English, while the Syrian flag representing Arabic and their nationality was placed on the rest of their bodies. Two young men drew the Union Jack on the core of 
their bodies. Four of the five self-portraits also emphasised that they liked or loved learning English through words written on the images, while also acknowledging the importance of speaking Arabic to their selfhood (see Figures 1-4).

Given the spatial norms that regulate the subject positions individuals are able to occupy (Valentine and Sporton, 2009), it is important to acknowledge the socio-spatial context within which the young people created their self-portraits. The young men all knew each other and were interested in photography, having previously received some training and worked together on a photography project over a number of weeks. Their familiarity with each other and with meeting together in the community space on Saturday mornings to work on a visual art project (Sime, 2015) helped to facilitate their self-portraits and the discussion which followed about English language and educational provision for newly-arrived young refugees.

None of the young men had studied English before they arrived in the UK under the resettlement programme for Syrian refugees following several years seeking refuge in Lebanon or Jordan. The young men's recent border-crossings and awareness of the power of the nation-state in categorizing who has a right to refuge and where, were also reflected in their self-portraits. Alamdar's self-portrait (Figure 1), for example, used the symbol of the Union Jack to denote not only the English language, but also to invoke discourses of nationhood and citizenship in the context of displacement from Syria due to the civil war:

I am from Syria. I recently arrived in London. I drew my country's flag on my chest and I drew United Kingdom's flag on my head because I love UK and I consider UK is my second state and I feel that I am one of its citizens. [...] I just know Arabic 
language when I came here, I started to learn English here and found it sweet and fun and most beautiful than other languages.

His representation of himself as embracing the UK as his 'second state' and enjoying learning English alludes to dominant narratives about integration and English language proficiency required in order to obtain employment and future citizenship within the neoliberal workfarist nation-state. As Antonsich (206, p.499) observes, "Citizenship is always a concession, never an objective right $[\ldots]$ The persistence of the neoliberal culturalist nation presides over the othering of the 'irregular' immigrants and the normalising of the 'regular' immigrant, but between these two positions there is a very thin (and farcical) line, as the latter is only an apparent condition of inclusion".

When asked "why is your body in Syria and your head is English or British?", Alamdar clarified:

Doesn't mean my body is there and my head is here. This means I am from Syria and I came to United Kingdom and I consider myself a new person here, I have coped with the weather here and love the people here. United Kingdom is big and great so I put it on my head.

His powerful narrative of hope and optimism for his imagined future in the UK, where he is able to reinvent himself as a 'new person' and present himself as distant from troubling emotions linked to his original 'homeland', is reflected in his chosen title for the portrait: 'Life is Beautiful'. His expressed love of the English language and strong appreciation for the opportunity to start a new life in UK could be read as an important counter-narrative in the Syrian refugees and young people of diverse African heritages in South-East England, Population, Space \& Place. 
context of the predominantly hostile political and media discourses about immigrants, Islamophobia and the portrayal of young Muslim men as a potential security threat (Clayton, 2019; Jones et al, 2017; Hopkins, 2007). Rather than seeking to emphasise his difference, Alamdar's narrative and posture convey a sense of openness to his adopted place of refuge and a strong desire for acceptance and integration in the UK. When asked about his imagined future, Alamdar seemed content to obtain work that enabled him to live well enough: "I don't have a big dream, I just want to have a simple job to live with".

The precariousness of Alamdar's claim to future citizenship in the UK is apparent in the underlying insistence on his suitability to be a productive future citizen and settle in the UK beyond the five years' allowance under the Humanitarian Resettlement Programme. As Antonsich comments, “Acceptance - however provision it might be - is indeed conditional on compliance with the national mainstream articulated in both culturalist (for example, home, family) and neoliberal (work) terms" (2017, p.499). Thus, Alamdar's narrative could be read as driven by the need to present himself as a 'deserving' and 'regular immigrant' who will conform to culturalist and neoliberal demands of the nation-state.

Similarly, Future's (20 yrs) self-portrait (Figure 2) emphasises the crucial importance of learning English in enabling him to fulfil his imagined future:

[English] I am from Syria, I came to England three months ago and I like to speak English, but I feel it is difficult, in future I hope to speak English well. [...] [Arabic] I put English language in my heart, because education first goes to brain and then feel it in the heart. 
Future placed a Union Jack flag on his head and on the left side of his body, containing his heart, while on the right side of his body, he drew the Syrian flag. The shape of the Union Jack gives the impression of a shield, which together with his posture, could be read as being prepared to defend himself and his imagined future in the UK through mastering the English language. His choice of pseudonym, 'Future' draws further attention to the temporality and futurity of the 'mobile transitions' in which he is engaged. Both Alamdar's and Future's selfrepresentations thus reveal the ways in which hegemonic discourses of the neoliberal culturalist nation (Antonsich, 2017), citizenship and normative youth transitions operate to discursively shape how young refugees themselves make meaning out of their own biographies (Robertson et al., 2017).

In contrast, two brothers who had arrived in the UK three months previously both expressed emotional distress and worry about family members left behind in Syria through their selfportraits and narratives. Syria Kid (aged 18) conveyed this clearly through writing in English on the portrait: 'My Heart in Syria, My Mind in UK', which he also chose as his title (Figure 3). He placed the Union Jack flag on his head and the Syrian flag on the rest of his body, except for his hand, which he coloured with red, white and blue of the Tricoleur flag representing France and the little French he knew. His narrative suggests that worry about his relatives and a sense of loss was felt in a very embodied way through pain in his heart:

RE: $\quad$ Tell us why your heart is in Syria and your mind is in the UK?

Syria Kid: This is normal because I was born in Syria, I grew up in Syria and I ate from its good things [Syria's produce] and my mind is in UK because I need to use my mind to learn and achieve my goals. I couldn't achieve my goals in my country, I came to UK to achieve my goals. [...] I want to study ICT. 
RE: $\quad$ Ok, you say your heart is still in Syria, do you have relatives there? Or is all your family here now?

Syria Kid: $\quad$ Sure I have family there and the people who die every day I think about it every time.

Syria Kid's narrative reveals strong emotional bonds and a wistful longing for his homeland which had nourished him as a child, which is also emphasised by his choice of pseudonym. His image and narrative also demonstrate the continuing embodied effects of multiple losses - of his homeland, family members who have died and those left behind who continue to suffer the effects of the civil war - that fill his thoughts and emotions. Simultaneously, however, the placing of the British flag on his head and his narrative demonstrates a strong desire to study and control his emotional distress in order to achieve his future aspirations in the UK. This suggests a potential struggle between the intellectual, rational mind and the heart, symbolising affect, representing this visually as an ambivalent, split self, which appears to be shaped by wider discourses of the mind-body split based on Cartesian logic that has structured 'Western' thought since the Enlightenment period.. Boccagni and Baldassar (2015, p.76) observe that, 'the co-existence of different, even conflicting emotional orientations can be seen as part and parcel of migrants' emotional experience', which is 'an open-ended process with no pre-determined outcome'. Furthermore, conflicting emotions and ambivalence towards the settlement country may be accompanied by complex timelines that young refugees must somehow hold in parallel, as Clayton explains:

first a notion of the life they had before whatever crisis made them leave - a life which can seem to them like a mythical and timeless Utopia; second, the journey with its ellipses and confusions, its stops and starts; and finally the rhythms of life in the host Syrian refugees and young people of diverse African heritages in South-East England, Population, Space \& Place. 
country, more orderly and regulated but always rushing towards a precarious outcome [...] - one which will hardly ever lead back to the precious safe remembered childhood place (Clayton, 2019, p.123).

His brother, King of Syria's image (Figure 3) also expresses a deep sense of belonging and attachment to his 'homeland' and emotional distress about family members left behind:

King of Syria: I am from Syria, I am 17 years old. I have been in the UK for three months now.

RE: $\quad$ You put the Syrian flag on your body?

King of Syria: Because all my thinking is about the homeland

Syria Kid: His mind is there because our grandparents, uncles, aunts and our cousins are (brother) there.

King of Syria's portrait, in which his whole body is covered with the Syrian flag from head to toe, is the only one of the young people's self-portraits that does not contain any symbols of the British nation, but he added in small blue font that he speaks Arabic and likes the English language. His narrative highlights the emotional distress, grief and potentially survivor guilt (Clayton, 2019), that refugees may experience in leaving behind or becoming separated from family members through displacement. It contrasts with his brother's portrayal that separates the mind from the corporeal body, where affect is portrayed as felt, suggesting here instead that emotions and thoughts are intertwined and cannot be separated. Further, his narrative and portrait indicate that his mind is elsewhere, located in Syria rather than being able to be present in his current location of the UK. Being filled with thoughts of loved ones and the 'homeland' that has been lost in this way may make it more difficult for some young people Syrian refugees and young people of diverse African heritages in South-East England, Population, Space \& Place. 
to embrace learning a new language and taking up educational, training or employment opportunities in settlement countries. The choice of title for his portrait, 'I love my family' also conveys the significance of his emotional bonds with family members to his relational subjectivity.

When reading the socio-spatial dynamics of the image, the word, Arabic, in large red font is placed across his legs and again in smaller purple font above his head, and his silhouette is roughly outlined with a thick red line, underscoring the centrality of Arabic to his identity. His arms are held up with little indication of any hands, which could be read as conveying a sense of helplessness, perhaps linked to his overwhelming loss and feelings about not being able to speak English. His choice of pseudonym (the King of Syria) reiterates this sense of belonging and attachment to his country of origin. Yet it also draws on a powerful alternative representation of the nation, suggesting potential resistance to the Syrian regime and a desire for mastery and control over what he has lost - his homeland, family members, friends and the perhaps previously taken-for-granted majority Arabic-speaking social and institutional environment. This could be interpreted according to Butler's (1997) ideas of the restrictive power of categorizations, which are particularly felt when people are not recognised as legitimate speakers of a specific language, or indeed as legitimate subjects (Nayak, 2017) or citizens (Antonsich, 2016), either in Syria or the UK. The King of Syria's categorization in the UK according to his legal status and ethnicity as a resettled Syrian refugee and the limited opportunities to express himself in his first language mean that educational and other institutional contexts may be experienced as restrictive, refusing a core part of his identity, while the self is also found to be lacking through an inability to communicate in English. 


\section{Hybrid subjectivities}

The self-portraits and narratives of diasporic youth of African heritage who had been born and grown up in multi-ethnic London were understandably more diverse than those of the group of young Syrian refugees, who had closer cultural and linguistic affinities and shared life experiences through protracted displacement from Syria and recent settlement in the UK. Migration studies often assume a straightforward distinction between 'first-' and 'secondgeneration' migrants' identifications with a 'homeland' and settlement communities, with less orientation to the former among 'second-generation' youth, based on a fixed sense of their spatio-temporality to the migration process (Roberston et al, 2017). A growing literature has pointed, however, to a more complex, open-ended process of emotional identification, with 'various degrees of hybridity between different emotional settings and referents' (Boccagni and Baldassar, 2015, p.76; Vertovec, 2001). In particular, work exploring African migrants' identifications across generations found that a 'transnational optic' was just as relevant for the children of first generation African migrants, but repertoires from 'homelands' were often less directly or intensively experienced by younger generations (Waite and Cook, 2012; McGregor, 2008; Evans, 2011).

In terms of the socio-spatial context, the workshop in London took place in a large room at an African diaspora organisation during a half-term school holiday; all the young people knew at least one other participant as a sibling or friend. The familiar community space where their 'African-ness' was valued may have facilitated young people's self-expression and willingness to share their heritage and translocal connections with peers from similar backgrounds. Processes of racialized 'Othering' in settings where young people of African heritages represent a minority and may be ascribed a 'black' identity by others and denied a British identity, such as in school or public spaces (Nayak, 2017), may inhibit such 
expressions of cultural identities. Indeed, attending to silences and what is 'un-sayable' (Butler, 1997), it is notable that none of the young people mentioned the homogenising identity category 'black', indicating, as Valentine and Sporton $(2009, \mathrm{p} .747)$ found, that 'it was not an identity that was emotionally or politically salient for them'.

Sarah and Amina who were of Somali heritage, both wore hijabs in the workshop. On their self-portraits (Figures $5 \& 6$ ), they both coloured the area of their headscarves green and copied from the internet white Arabic script to place on this part of their body. In their narratives, they explained that this was the flag of Saudi Arabia which symbolised their religious affiliation to Islam. The flag of Saudi Arabic is green, representing Islam, with a white inscription of the Islamic creed, or shahada: "There is no god but Allah; Muhammad is the Messenger of God", with a white sword underneath which symbolises strictness in applying justice (Wikipedia, 2019). Both Sarah and Amina chose to omit the sword from their signifiers of Saudi Arabia, Islam and the Arabic language.

Sarah expressed her relational selfhood in terms of multilocal attachments to Somalia, England, Saudi Arabia and Italy (Figure 5). Her narrative suggests that she identified with her Somali heritage by placing the Somali flag on her face, but also alluded to processes of racialised 'Othering', by highlighting the fact that her facial features were read by others as Somali:

The flags that I have on it is the Somali flag, the British flag, the Italian flag and the Saudi Arabian flag. I chose the Somali flag to put on my face because my heritage was Somali and you can tell I'm Somali by my face. Then I put the top half of my body as the English flag because I was born and raised here. I put my headscarf as the Syrian refugees and young people of diverse African heritages in South-East England, Population, Space \& Place. 
Saudi Arabian flag because I can read and write Arabic. I drew the Italian on the bottom of my leg because my sisters were born there and my mum and my sisters speak Italian.

The socio-spatial effects of the image also support a reading of Sarah's subjectivity as hybrid and multilocal. She recognises how central the English language and her 'Britishness' are to her embodied identity, but she is wearing (literally and metaphorically) her Somali and Muslim/ Arabic-speaking identities on her face, head and shoulders, signifying perhaps that she perceived by others and positioned according to these markers of racial and religious difference rather than as British (Valentine and Sporton, 2009; Dwyer, 1999). This hybrid, multiple sense of self is reflected in her title: 'Me, myself and I'.

As indicated in her narrative, Sarah's identity and linguistic repertoire were also shaped by close family members' migration trajectories and linguistic practices. Drawing on Derrida's (1998) idea that linguistic repertoires include categories which are refused to one and a desire for what one does not have (Busch, 2012), the symbol of the Italian language placed on Sarah's body, despite not speaking Italian herself, could be read as a sense of desire and longing to identify with Italy in the same way as her mother and sisters did. The placing of this emotional connection to Italy on her legs invokes movement, mobility and travel and could be interpreted as signifying her desire to continue travelling to and from Italy and maintaining her links to relatives there and identification with her family's migration trajectory, within in a UK context where she is read as 'Other'.

Amina, another young woman of Somali heritage, located her Somali identity in the core part of her body, using a square of the blue Somali flag to symbolise this (Figure 6). Her Syrian refugees and young people of diverse African heritages in South-East England, Population, Space \& Place. 
positioning of the Union Jack flag, symbol of British nationhood, on her feet could be seen as grounding her. The speech bubble she has added saying 'barely British' however suggests she sought ironically to distance herself from hegemonic exclusionary narratives of nationalism and British imperialism. Her narrative also suggests that she took for granted her English language fluency and did not value it as much as her religious, cultural and migrant identities which positioned her as 'different':

Amina: $\quad$ I drew Saudi Arabia because Saudi Arabia has Mecca and I'm really religious. I drew Somalia because that's where I'm from and I speak the language, Somali. I did Italy. It got covered up a little bit, but it's because my parents used to live there for a while and we'd go there all the time. There's the British flag but I just didn't have anywhere else to put it, so I just put it on my feet, but I speak English.

RE: Okay. Do you speak Somali at home with relatives?

Amina: $\quad$ Yes, all the time.

Sarah and Amina appeared to be proud of their Somali heritage and fluency in Somali language. When attending to silences and what is 'un-sayable' (Butler, 1997; Busch, 2010), Amina's narrative can be seen as actively resisting racialised processes of 'Othering' that may position her as 'Black British', according to institutional ethnicity categories, choosing instead to emphasise her Muslim and Somali identities, with a family migration history linked to Italy (in the same way as Sarah). As Valentine and Sporton's (2009) research with young people of Somali heritage found, the subject position, Muslim, overcame some of the troubling aspects of other subject positions which could be associated with a denial of Britishness and dis-identification with being black/Black. Sarah and Amina's narratives Syrian refugees and young people of diverse African heritages in South-East England, Population, Space \& Place. 
point to the ambiguities associated with Britishness for young Muslim women of Somali heritage growing up in a monolingual, multicultural society that often positions young (male) Muslims as a potential security threat (Robertson et al, 2017; Hopkins, 2007). Sarah and Amina's narratives and self-portraits also point to a sense of pride in their religious identities as young Muslim women, signified by wearing the hijab. As other studies of young British Muslim women (predominantly of Asian heritages) have shown, young women negotiate their identities "by focusing on dress as an overdetermined signifier of difference" (Dwyer, 1999, p.21). Young women may wear the hijab to demonstrate their obedience to their faith and enjoy the status and respect that this accords, as well as to police the male gaze (Siraj, 2011) and dis-identify with other racialized identity categories (Valentine and Sporton, 2009).

Robert and his sister Lilly, of Congolese heritage also portrayed hybrid subjectivities using key signifiers of nationhood in their artistic self-portraits (Figures $7 \& 8$ ). Robert's image and narrative focused on the duality of his English and Congolese heritage, using the colours of the flags of the UK and the Democratic Republic of Congo (DRC) on each side of his body:

I've put on one side that I'm from Congo and on the right side of my face, I tried to put the colours of the Congolese flag on my face with the star. On the other side of my face, I put the colours of England, here, because I was born here.

He carefully outlined the shape of his body with these different colours on each side and included a St. George's cross, the red and white England flag, on his neck, while the core of his body is covered with the yellow stars of the DRC flag. The choice to place the bright Syrian refugees and young people of diverse African heritages in South-East England, Population, Space \& Place. 
Congolese stars on his chest, flowing out casually from his hoodie, could be read as showing strong emotional connections to his Congolese roots, associated with close family ties.

Meanwhile, the St. George's cross located on his neck has the effect of appearing like a formal collar, and could be read as constraining the movement of his body and perhaps his vocal cords, a signifier of his speaking or language abilities. In this interpretation, Robert's claim to a legitimate English identity could be read as rather ambivalent, unsure whether 'Englishness' forms a core part of his relational self, or whether it is at odds with his Congolese heritage. As Nayak (2007, p.297) suggests, racism is "pressed on to the bodies of Others, to the extent that it comes to regulate their mobility, displace them 'back to the jungle' and in doing so purge the nation from migrant belonging". Thus, "making the white nation" is not only a social and material act, but connects with "deeper psycho-social feelings related to whiteness and national belonging regarding who 'really' has a right to belong" (ibid, p.290).

Robert's hybrid, ambivalent sense of belonging to two cultures, but not being able to identity fully with one or the other is also reflected in his narrative:

RE: $\quad$ Do you speak the languages of DRC, is it Kiswahili...?

Robert: In Congo, we speak French, Lingala and Swahili. I can't speak French and Lingala, but I can understand some of it.

RE: $\quad$ Does your mum teach you?

Robert: $\quad$ She doesn't teach me them, she just sometimes speaks to me in French and Lingala, but I can't respond back. So, I can't speak it. 
His lack of proficiency in speaking French and Lingala is emphasised (mentioned three times), reflecting Derrida's (1998) understanding of multilingualism as being about loss and a desire for what one lacks. Robert's use of personal pronouns is also interesting, using the confident, 'we' to talk in more general terms about the DRC, including himself in this cultural sphere of knowledge, but then shifting to 'I' when expressing regret that he was not able to speak two of the major named languages. He seemed painfully aware that he was not recognised as a legitimate speaker of these languages (Butler, 1997), expressing frustration in not being able to speak or respond to his mother in French or Lingala. Robert chose to write the title of his self-portrait in French: J'aime ma pais, meaning, 'I love my peace', influenced by his sister's use of French in her title (Figure 8). The fact that the French word 'pais' is misspelt (the usual French spelling is 'paix') highlights the provisional, uncertain nature of Robert's identification with his French-speaking post-colonial heritage and the fact that for him, French may remain a primarily spoken rather than written language. It could also be read as a translanguaging practice (Wei, 2018), demonstrating fluid mobility and mixing of English and French to create new hybrid linguistic forms.

The image created by Hope (Figure 9), whose Zimbabwean mother had sought asylum in the UK, contrasts to the other self-portraits in terms of multilingualism and the lack of representation of her parents' countries of origin. Hope used the colours of the Union Jack flag over her face to represent speaking English. Seeing the other young people include African languages on their portraits, Hope said that she only spoke English and did not know what else to put on her portrait. When I responded saying she could represent anything she wanted about herself, she decided to include a the sign language that she was learning in a speech bubble, alongside another bubble with the word, 'English', superimposed on the core of her body. Syrian refugees and young people of diverse African heritages in South-East England, Population, Space \& Place. 
The lack of any signs of Zimbabwean nationhood, such as a flag of Zimbabwe, colours or symbols, to represent her Zimbabwean heritage suggest a strong identification with English, as her first language. This perhaps also reflects her parents' family language policy of speaking English at home; she acknowledged that her mother had only taught her and her brothers a few words of Shona. Hope's hesitancy about what to include on her self-portrait and the lack of any signifiers of Zimbabwe could also be read as (emotional) ambivalence (Boccagni \& Baldassar, 2015) and a sense of distance from her mother's country of origin. This may be related to geo-political power geometries, including the legacy of British colonialism in a country which only became independent in 1980, dominance of the English language in the education system and public sphere, dis-identification with the actions of the former President Robert Mugabe and a desire for distancing from the political turmoil in Zimbabwe in recent decades. Hope said that she had visited her grandmother and other relatives in Zimbabwe and spoke to them regularly on the phone, but explained it was difficult to communicate with her grandmother more recently, as she did not speak much English and had dementia. Her speech bubble referring to her ability to use sign language suggests her desire to express something more about her identity than just her 'Britishness' and an alternative means of communicating than only speaking English.

Hope mentioned in the workshop that she was living with chronic pain due to joint hypomobility, which is perhaps alluded to the use of the word 'existence' in her chosen title (Growth within existence). At a community event organised by the diaspora organisation, I observed Hope performing a song she had composed about her feelings about the domestic violence that her mother experienced. Her moving performance in a quiet voice suggests that creativity in music may be an important resource which enables her to express some of the Syrian refugees and young people of diverse African heritages in South-East England, Population, Space \& Place. 
(emotional/physical) pain she feels. Hope's slightly slumped posture in the self-portrait could also be interpreted as being burdened by pain and/or problems which may be 'un-sayable' in everyday language, finding expression instead in her song lyrics. This context thus may represent some of the 'absent realities' of the image produced (Breckner, 2007), although this reading is subjective. Her chosen pseudonym, Hope, and the word 'growth' in her title however suggest moving forward towards a more hopeful future and developing new interests, such as sign-language, despite difficult experiences.

\section{'Contrapuntal' analysis of the self-portraits}

All of the young people participating in the research used a national flag and/or colours of the flag to symbolise speaking particular named languages and their emotional connections to different countries and marked these on their body shape, as previous approaches to language portraits have also found (Busch, 2012; Coffey, 2015). The creative visual methodology and use of digital photography and collage art software with ipads, however, enabled young people to create a self-portrait of their own bodies that was personal and enabled them to express more about their own identity, translocal emotions and belonging than is usually the case in conventional language portrait methods. It is nevertheless important to recognise the subjective nature of my reading of the images and multiple ways they could be interpreted.

The self-portraits created by recently arrived Syrian young men living in Reading contrasted sharply with those produced by diasporic young people of African heritage in London, in terms of the importance attributed to the English language and representations of British nationhood. While only one of the young people born in the UK located a Union Jack flag on their head, four of the five Syrian young men placed the Union Jack flag on their head or core 
of their bodies. Their positive attitudes towards language learning contrast with the narratives of the young people of African heritages. It is particularly interesting to juxtapose Robert's narrative, which emphasised what he could not do, that is, not being able to speak French or Lingala, with the Syrian young men's optimistic perspectives on learning English, despite the challenges they shared. Indeed, when analysing silences and what is 'un-sayable' (Butler, 1997), none of the Syrian young men said they could not speak English or used other negative verb formations about their language proficiency, but rather emphasised the language learning process they were engaged in. This observation could be a feature of the lexicon used in Arabic and how this was translated into English. The optimistic language used about learning English could also be interpreted, however, as young men's attempts to position themselves within dominant narratives of 'integration' and citizenship in the monolingual context of the UK. In their experience, English language was the "key that can open all the doors" (the literal Arabic translation of their words here was "you can get your dreams"); that is, it was necessary to access further education and training, higher education and employment, providing the gateway to future citizenship in the UK, as part of the neoliberal culturalist nation (Antonsich, 2016).

Furthermore, despite clearly identifying as Muslim when asked about their biographical details at the end of the workshop, the Syrian young men did not wish or feel the need to represent this on their portraits, in contrast to Amina's and Sarah's representations of Islam on their headscarves. This 'absent reality' (Breckner, 2007) points to the gendered, intersectional nature of processes of racialized 'Othering' which position young women who wear a headscarf in the UK as Muslim 'Others' (Dwyer, 1999), despite being born in the UK, while recently arrived Syrian young men may not be read so obviously as Muslim from their appearance (Hopkins, 2007). This omission can also be regarded as a (perhaps unconscious) Syrian refugees and young people of diverse African heritages in South-East England, Population, Space \& Place. 
attempt by the young men to distance themselves from racialized, Islamophobic narratives that specifically construct young Muslim men as a threat.

Furthermore, when asked at the end of the workshop in London if they were aware whether their parents had migrated to the UK as refugees and sought asylum prior to applying for British citizenship, some young people of diverse African heritages did not know if they came from a refugee or other migrant background. Stories of the older generation's migration trajectories and potentially stigmatising immigration labels based on their legal status as asylum-seekers, refugees, visa overstayers, 'illegal' (undocumented) immigrants, may be deemed 'un-sayable' (Butler, 1997) within families or considered irrelevant to young people's lives when they were born and raised in the UK. This demonstrates the restrictive power of categorisations (Butler, 1997) and highlights the inappropriateness of bounded typologies of migrants, calling into question whether these young people should be viewed primarily through a migration lens. Indeed, a focus on 'translocal/ transnational youth' or 'diasporic youth' may be a more appropriate way of capturing the complexities and overlapping forms of young people's mobilities in such multi-ethnic urban contexts (Robertson et al., 2017).

Nevertheless, it should be acknowledged that parents may try to protect their children from the burden of negative experiences or traumas experienced in past times and places associated with migration and resettlement journeys (Valentine and Sporton, 2009; Boccagni and Baldassar, 2015). Parents', siblings' and older generations' migration trajectories and memories may therefore form an important part of the social context which, although not directly accessible to young people, may be passed on from one generation to the next Syrian refugees and young people of diverse African heritages in South-East England, Population, Space \& Place. 
through silences, avoidances or 'hauntings' (Fewell, 2016), shaping young people's emotional worlds and translocal connections.

\section{Mapping translocal relationality in the superdiverse city}

While the self-portraits have much to say about young people's translocal subjectivities, relationality was explored in more depth in the world map art work (Figures 10, 11 \& 12) of translocal emotional connections produced with young people of African heritages in London. The personal community mapping exercise revealed a wide range of translocal emotional connections and diverse social networks with close and extended family members, friends and acquaintances which shaped young people's subjectivities and multi-local senses of belonging to London and different places globally. For example, Amina described her cousin, who had lived with her family for several years but moved back to the US, as her sister and best friend:

\footnotetext{
"My cousin, she lived with us for a while for about five years. She basically became my sister. She was like my best friend, like we were inseparable. [...] Her family lives in America, so she went back to stay with them [...] My cousin did come around this summer and it was really fun".
}

Similarly, Hope emphasised the closeness of her kin-like relationship with her friend, developed through shared domestic routines and company in homespace:

"She's practically a sister and she's lived with us on and off for a long time, not purposefully but accidently just stayed for a couple of weeks. She supports me, gives 
me advice, she makes me laugh. She makes my brothers laugh and it's just a nice vibe when she's around".

These experiences suggest fluid understandings of sibling ties and kinship commonly expressed in African contexts (Evans, 2011; 2014), but which may deviate from dominant narratives of the 'nuclear family' in the UK that prioritise parental care of children and biological sibling bonds over those of cousins or kin-like friendships.

Young people also identified meaningful relationships of care and support with relatives living at a distance - in Eastern and West Africa, the US and other European countries as well as in other cities in the UK. Sarah, for example, included on her map the care that she and her family provided for her nephew who lived in Kenya in the form of remittances and gifts. She also had cousins living in Germany and in Manchester whom she saw regularly and aunts and uncles living in Somalia, whom she had never met, while others lived in the US.

The importance of these translocal relationships to young people's hybrid subjectivities was apparent when they produced the collective world map of their translocal emotional connections (Figures 10, $11 \& 12$ ). Young people chose which relationships they wished to write about and attached a thread linking London to where family members were from and where their relatives and friends lived globally. Amina, for example, wrote about her relationship with her cousin, whom she regarded as a sister, on the map of translocal connections, with a thread from London to the US, and Hope highlighted her relationship with her aunt in Ghana (Figure 11). Sarah emphasised the care and support she gave and received through close and more distant relationships with family members in Somalia (Figure 12). When discussing the overall message they wanted to convey to the public about Syrian refugees and young people of diverse African heritages in South-East England, Population, Space \& Place. 
their map, young people emphasised their multicultural diversity and how multi-local attachments and migration processes shaped identities in London:

RE: Okay, so have you got something that you want to tell people about your experiences?

Hope: $\quad$ It's a multicultural melting-pot.

RE: $\quad$ Yes ...multicultural melting-pot, what do you think?

Amina: It's diverse, like today, everyone has said that - it's not just Africa, there's Somali, Congolese, Zimbabwean, Ghanaian, there's lots of...

RE: $\quad$ Yes. So what do you think the message should be then, on the map?

Sarah: $\quad$ That no one is the same - everyone's got their background and their own stories to tell.

Amina: Diversity...

Sarah: $\quad$ No one's really the same. Everyone has different backgrounds. [...] Like, no one's originally from one place. Like my mum, she was born and raised in Somalia and then she travelled to Italy and she brought up my sisters for a few years and then she came to the UK. She has, like, seen different...different cultures; she's adapted to them and stuff like that.

Young people drew here on inclusive discourses of multiculturalism and diversity to characterise their experiences, recognising the translocal nature of attachments to place in 'superdiverse' London. The final title they chose, 'London is diverse, no-one is the same!', reflects this recognition of the plurality and diversity of subjectivities, cultures and migration stories in the multi-ethnic city, which seemed to be underpinned by a sense of belonging and pride in the city where they had been born and raised. This provides an important counterSyrian refugees and young people of diverse African heritages in South-East England, Population, Space \& Place. 
narrative of "tolerance, resistance and slow-burn multiculturalism" which may help to corrode exclusionary notions of nationhood and citizenship (Nayak, 2017, p.290). As Nayak aptly puts it, young people's agency is revealed through such “appeals to a new urban citizenship, signalled through birth-rights, shared schooling experiences, rights to the city and multicultural forms of Britishness deployed to recalibrate nationhood and belonging" (ibid, p.300).

\section{Conclusion}

This paper has explored diverse visual and narrative constructions of young people's translocal subjectivities in contexts of displacement, resettlement and superdiversity in London and Reading, South-East England. The placing of signs of the British nation-state on the heads of young Syrian refugees signifies the crucial importance they placed on learning English and becoming 'integrated' as present 'bilingual becomings' and future citizens in the UK. The optimistic language used about the process of learning English, however is perhaps surprising, given their limited proficiency in English and frustrations they expressed about aged-based restrictions on access to English language learning and other educational provision in the UK. However, hegemonic narratives about the importance of speaking English for 'integration' and whom may claim citizenship in the UK, alongside Islamophobia and perceptions of young Muslim men as a potential security threat (Hopkins, 2016; Clayton, 2019), represent salient absent realities (Breckner, 2007) without which their images and narratives are incomprehensible. Such social contexts may result in feelings of discomfort, unease and the need to be seen to 'fit in' among many migrant youth and minorities, which operates to instil a sense of being "illegitimate" citizens (Nayak, 2017, p.294). 
The visual embodied method used enabled young men to express deep translocal emotional attachments to people left behind in Syria and to acknowledge the distress and anxiety they felt in their 'hearts', which sometimes also filled their 'minds'. A strong sense of belonging to their 'homeland' felt by some made it difficult for them to embrace educational opportunities in the new place of resettlement in which they found themselves. Indeed, young people's hopeful imaginaries of vocational training, university education, employment and future citizenship in the UK, powerful signifiers of belonging and socially expected youth transitions, are thrown into sharp relief by their powerlessness in determining the country in which they would be 'resettled' and to which they would be formally entitled to 'belong' prior to arrival in the UK. They also lacked information about future educational opportunities, following several years of disrupted education in Syria, Jordan and Lebanon. Given such protracted educational transitions (Robertson et al, 2017), young men's strong desire to learn and speak English within months, rather than years, is understandable and key to their imagined futures. The young men thus predominantly represented themselves as 'bilingual becomings', engaged in important educational transitions in the pathway towards independent adulthood and becoming a 'productive citizen' within the neoliberal culturalist nation (Antonsich, 2016), despite the complexity and non-linear pathways of contemporary 'mobile transitions' (Robertson et al, 2017).

A sharp contrast was apparent in the significance placed on the English language by the young Syrian refugees compared to the ways that speaking English was sometimes taken for granted in the self-portraits of young people of diverse African heritages born in the UK. Indeed, Sarah's self-portrait suggests a sense of resistance and dis-identification with Britishness, signified by the Union Jack flag placed on her feet with the speech bubble, 'barely British'. Valentine and Sporton's (2009, p.738) argue that the identity categories Syrian refugees and young people of diverse African heritages in South-East England, Population, Space \& Place. 
'English' and 'British' are still predominantly racialized as white identities that are 'largely unfragmented by multicultural experiences'. Young people's ambiguous identifications with Britishness despite being born in the UK and growing up in London suggest that this observation is still salient despite the superdiversity evident in their 'home' city.

Furthermore, as Waite and Cook (2012) found, younger generations of African migrants did not generally articulate a sense of 'African-ness', but rather expressed their selfhood and belonging through national, ethnic and religious identifications. Both Sarah and Amina emphasised their Arabic-speaking Muslim and Somali identities, demonstrating their strong emotional investments in these identity categories which provided a means of sidestepping hegemonic representations and categorisations of "black Britishness/ black African-ness" (Valentine and Sporton, 2009). Young people of Congolese heritage also expressed a sense of hybrid relational selfhood that recognised their English/British identities and Congolese emotional connections through their parents' migration histories. Meanwhile, Hope's image contained no signifiers of Zimbabwean nationhood or indigenous languages, suggesting the possible dominance of English in family language policies among the Zimbabwean diaspora and the ambiguous nature of identifications among British-Zimbabwean young people linked to colonialism and more recent socio-political histories (McGregor, 2008).

Despite a shared sense of emotional ambivalence evident in both groups of young people, pride in their hybrid cultural heritages, multilingual identities, translocal place-attachments and migration histories provide hopeful counter-narratives to exclusionary nationalist discourses and racialized processes of 'Othering', particularly those of 'Black African' youth and Muslim young men. Indeed, young people's art work throws light on the restrictive nature of institutional categories (Butler, 1997) and hostile language used about immigrants, Syrian refugees and young people of diverse African heritages in South-East England, Population, Space \& Place. 
citizenship, race, ethnicity and youth which glosses over the diversity of embodied hybrid subjectivities and translocal relationality that young people navigate in their everyday lives.

Further research could fruitfully build on the innovative methodology and intersectional approach adopted in this project to explore changing geographies of translocal youth mobilities within contexts of whiteness as well as superdiversity (Nayak, 2017). The 'contrapuntal' analysis of self-representations and translocal emotional worlds of recently arrived Syrian young men and diasporic young people of diverse African heritages reveals the value of exploring divergent 'types' of translocal youth mobility within the same study (Robertson et al, 2017). Such work needs to start from an understanding of the complexities and ambiguities of young people's multilingual, relational selves and translocal emotional geographies that may be shaped more by wider socio-political narratives of nationhood, citizenship and migration than may, at first, be apparent. Translocal youth may embrace signifiers of national, religious and cultural identity, but through their silences and omissions, dis-identify with exclusionary notions of 'Britishness', nationhood and citizenship, as well as racialized, often gendered, youth and immigrant identity categories. This underscores the importance of analysing wider socio-political discourses, silences and what is avoided or deemed 'un-sayable' (Butler, 1997; White and Tyrell, 2015) in different social contexts, since these may represent crucial 'absent realities' (Breckner, 2007) without which young people's translocal relational subjectivities and embodied performances are incomprehensible.

\section{Acknowledgements}

I wish to thank the young people who participated in the research for the vibrant artwork they produced and for sharing their experiences with me. I am very grateful to Africa Advocacy Foundation, Reading Refugee Support Group and Parwin Hama-Khan for their assistance in 
facilitating the research. I am also grateful to the University of Reading for funding this research project. 


\section{References}

Ansell, N. (2009). Childhood and the politics of scale: descaling children's geographies. Progress in Human Geography, 190-209.

Antonsich, M. (2016). The neoliberal cultural assassination: voices from Italy. Transactions of the Institute of British Geographers, 41, 490-502.

Askins, K. (2015). Being Together: Everyday Geographies and the Quiet Politics of Belonging . ACME, 470-478.

Barber, T. (2015). Performing 'Oriental' masculinities: embodied identities among Vietnamese men in London. Gender, Place and Culture, 22(3), 440-455.

Blazek, M., \& Windram-Geddes, M. (2013). Editorial: Thinking and doing children's emotional geographies. Emotion, Place and Society, 9, 1-3.

Boccagni, P., \& Baldassar, L. (2015). Emotions on the move: mapping the emergent field of emotion and migration. Emotion, Space and Society, 73-80.

Breckner, R. (2007). Pictured bodies. A methodical photo analysis. Interaction Interview, 125-140.

Busch, B. (2012). The linguistic repertoire revisited. Applied Linguistics, 1-22.

Butler, J. (1997). Excitable Speech. A politics of the performative. Routledge.

Clayton, S. (2019) narrating the young migrant journey: themes of self representation. In S.Clayton, A.Dr and K.Willis (Eds. ) Unaccompanied Young Migrants. Identity, Care and Justice. Bristol: Policy press, pp.115-133.

Conradson, D., \& McKay, D. (2007). Translocal subjectivities: mobility, connection, emotion. Mobilities, 167-174. 
Cook, J., \& Waite, L. (2016). 'I think I'm more free with them'-Conflict, Negotiation and Change in Intergenerational Relations in African Families Living in Britain . Journal of Ethnic and Migration Studies, 1388-1402.

Derrida, J. (1998). Monolingualism of the Other or the Prosthesis of Origin. Stanford: Stanford University Press.

Dwyer, C. (1999). Veiled Meanings: Young British Muslim Women and the Negotiations of Differences . ender, Place and Culture 6, 1, 5-26.

Evans, R. (2011) Young caregiving and HIV in the UK: caring relationships and mobilities in African migrant families. Population, Space \& Place, 17, 4, 338-360.

Evans, R. (2014) Parental death as a vital conjuncture? Intergenerational care and responsibility following bereavement in Senegal. Social \& Cultural Geography, 15, 5, $547-570$.

Farmer, D., \& Cepin, J. (2015). Creative Visual Methods in Research with Children and Young People. In R. Evans \& L. Holt (Eds.), Methodological Approaches. Geographies of Children and Young People. Vol. 2 (Editor-in-chief: T. Skelton). Singapore: Springer.

Fewell, J. (2016). Tattered scripts: Stories about the transmission of trauma across generations. Emotion, Space and Society, 19, 81-86.

Garcia, O., \& Wei, L. (2014). Translanguaging. Language, Bilingualism and Education. Palgrave MacMillan.

Grant, T. (2015). Participatory Research with Children and Young People: Using Visual, Creative, Diagram, and Written Techniques. In R. Evans, \& L. Holt (Eds.), Methodological Approaches, Geographies of Children and Young People. Vol. 2 (Editor-in-chief: T. Skelton). Singapore: Springer. 
Greiner, C., \& Sakdapolrak, P. (2013). Translocality: concepts, applications and emerging research perspectives. Geography Compass, 373-384.

Hopkins, P. (2007). Young people, masculinities, religion and race: new social geographies. Progress in Human Geography, 163-177.

Hopkins, P. (2016). Gendering Islamophobia, racism and White supremacy. Dialogues in Human Geography, 186-189.

Hopkins, P. (2017) Social geography 1: Intersectionality, Progress in Human Geography, 111.

Hopkins, P., \& Alexander, A. (2010). Politics, mobility and nationhood: upscaling young people's geographies. Area, 142-144.

Jones, H., Gunaratnam, Y., Dhaliwal, S., Davies, W., Jackson, E., Bhattacharyya, G., et al. (2017). Go Home? The Politics of Immigration Controversies. Manchester: Manchester University Press.

Massey, D. (1994). A Global Sense of Place. In D. Massey, Place, Space and Gender.

Mayblin, L., \& James, P. (2018). Asylum and refugee support in the UK: civil society filling the gaps? . Journal of Ethnic and Migration Studies, 375-394.

McGregor J. (2008). Children and 'African values': Zimbabwean professionals in Britain reconfiguring family life. Environment and Planning A 40: 596-614.

Mee, K., \& Wright, S. (2009). Geographies of belonging. Environment and Planning A 41, 4, $772-779$.

Nayak, A. (2017). Purging the nation: race, conviviality and embodied encounters in the lives of British Bangladeshi Muslim young women. Transactions of the Institute of British Geographers, 42, 289-302. 
Ní Laoire, C. Carpena-Méndez, F. Tyrrell, N. \& White, A. (2010).

Introduction: Childhood and migration mobilities, homes and belongings.

Childhood: Global Journal of Child Research, 17(2), 155-16.

Robertson, S., Harris, A., \& Baldassar, L. (2017). Mobile transitions: a conceptual framework for researching a generation on the move. Journal of Youth Studies.

Rose, G. (2016). Visual Methodologies. An Introduction to Researching with Visual Materials. 4th Edition. London: Sage.

Sime, D. (2015). Challenging barriers to participation : doing research with migrant children and young people. In R. Evans, \& L. Holt, Methodological Approaches. Geographies of Children and Young People, Volume 2 (Editor-in-Chief: T. Skelton). Singapore: Springer

Siraj, A. (2011). Meanings of modesty and the hijab amonst Muslim women in Glasgow, Scotland. Gender, Place and Culture, 18(6), 716-731.

Spencer, L., \& Pahl, R. E. (2006). Rethinking friendship: hidden solidarities today. Princeton,: Princeton University Press.

Staeheli, L., \& Ehrkamp, P. L. (2012). Dreaming the ordinary: Daily life and the complex geographies of citizenship. Progress in Human Geography, 628-644.

Valentine, G., \& Skelton, T. (2005). Cool Places. Geographies of Youth Cultures. London: Routledge.

Valentine, G., \& Sporton, D. (2009). 'How Other People See You, It's Like Nothing That's Inside': The Impact of Processes of Disidentification and Disavowal on Young People's Subjectivities. Sociology, 735.

Vertovec, S. (2001). Transnationalism and identity. Journal of Ethnic and Migration Studies, 27(4), 573-582. Syrian refugees and young people of diverse African heritages in South-East England, Population, Space \& Place. 
Waite, L., \& Cook, J. (2012). Belonging among Diasporic African Communities in the UK: Translocalism and Plurilocal Homelands. Emotion, Space and Society 41, 238-248.

Wei, L. (2018). Translanguaging as a Practical Theory of Language. Applied Linguistics 39, $1,9-30$.

White, A. \& Tyrell, N. (2015). Research with Children Seeking Asylum in Ireland:

Reflecting on Silences and Hushed Voices. In R. Evans, \& L. Holt (Eds.), Methodological Approaches, Geographies of Children and Young People. Vol. 2 (Editor-in-chief: T. Skelton). Singapore: Springer.

Wikipedia. (2019). Flag of Saudi Arabia. Available from: https://en.wikipedia.org/wiki/B2B Flag_of_Saudi_Arabia [accessed 7/3/19].

Figures and captions for paper: Picturing translocal youth: self-portraits of young Syrian refugees and young people of diverse African heritages in South-East England

Figure 1

Alamdar (aged 19): Life is Beautiful 


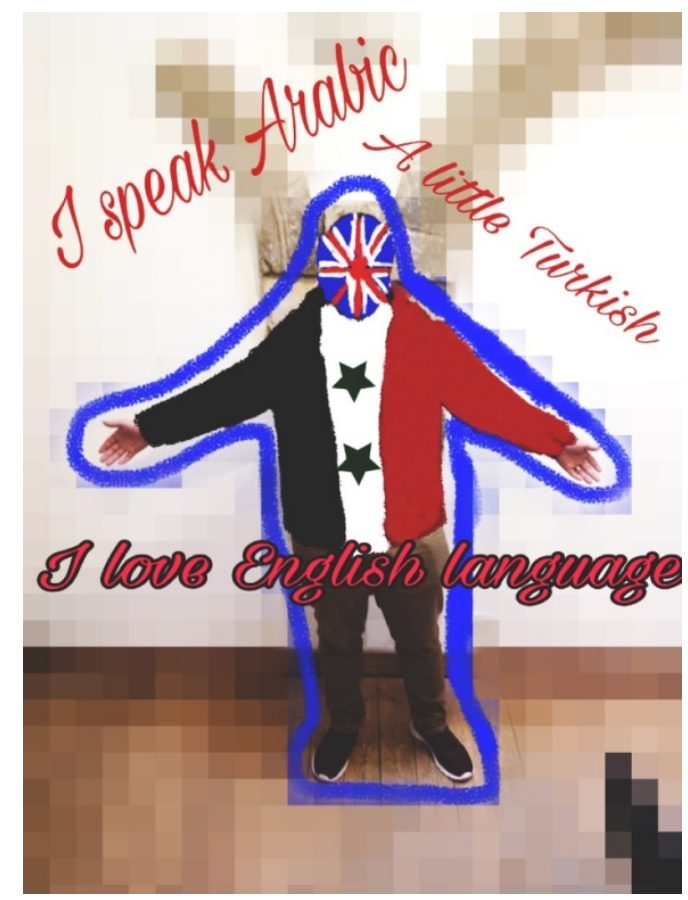

Figure 2

Future (20 yrs): I like Lerning

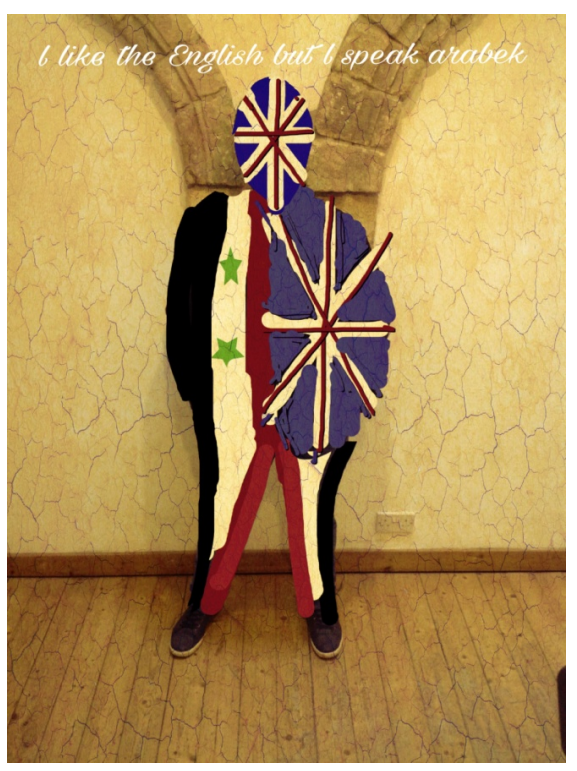

Figure 3

Syria Kid (aged 18): My Heart in Syria, My Mind in UK

(C) Ruth Evans, 26/6/19. Please cite as Evans, R. (in press) Picturing translocal youth: self-portraits of young Syrian refugees and young people of diverse African heritages in South-East England, Population, Space \& Place. 


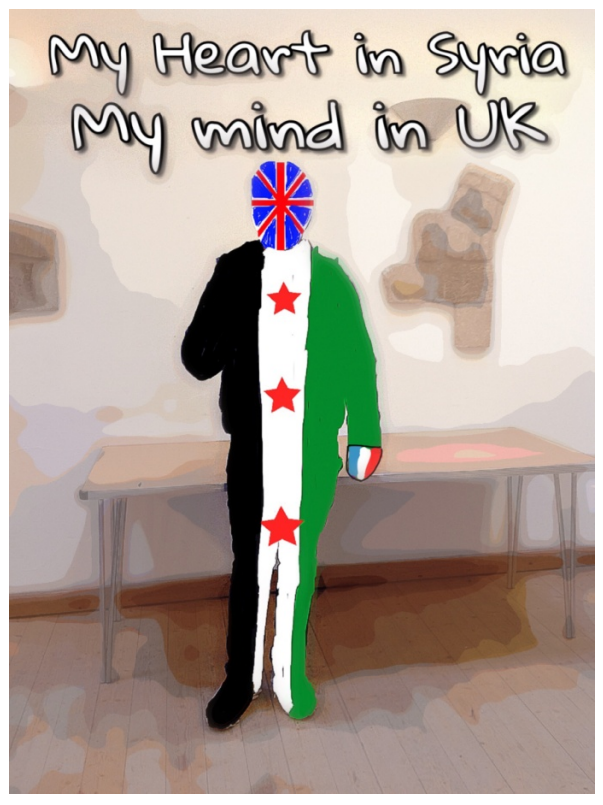

Figure 4

The King of Syria (aged 17): I love my family

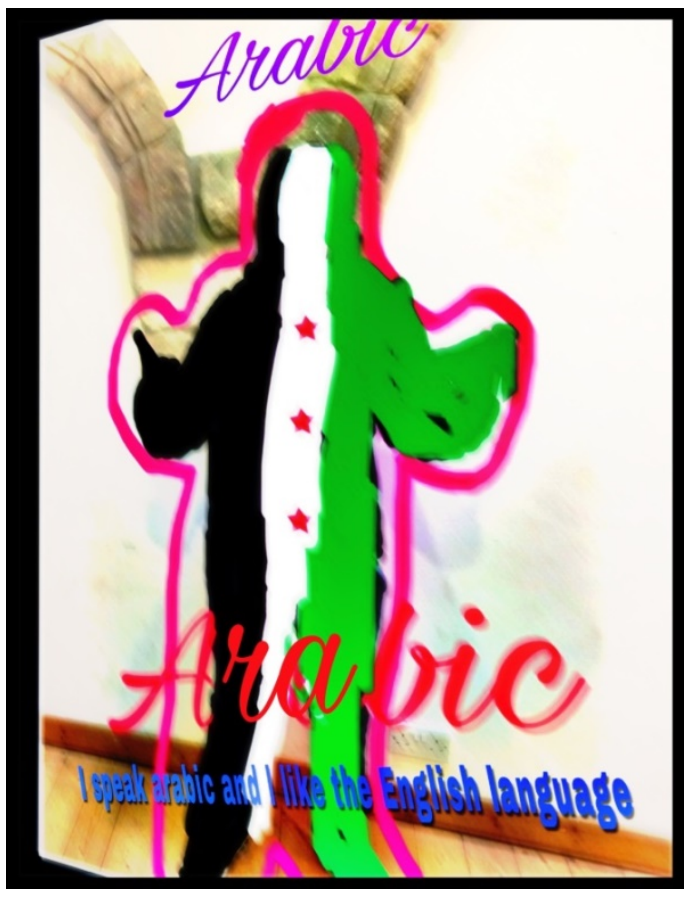

Figure 5

Sarah, aged 17: Me, myself and I

(C) Ruth Evans, 26/6/19. Please cite as Evans, R. (in press) Picturing translocal youth: self-portraits of young Syrian refugees and young people of diverse African heritages in South-East England, Population, Space \& Place. 


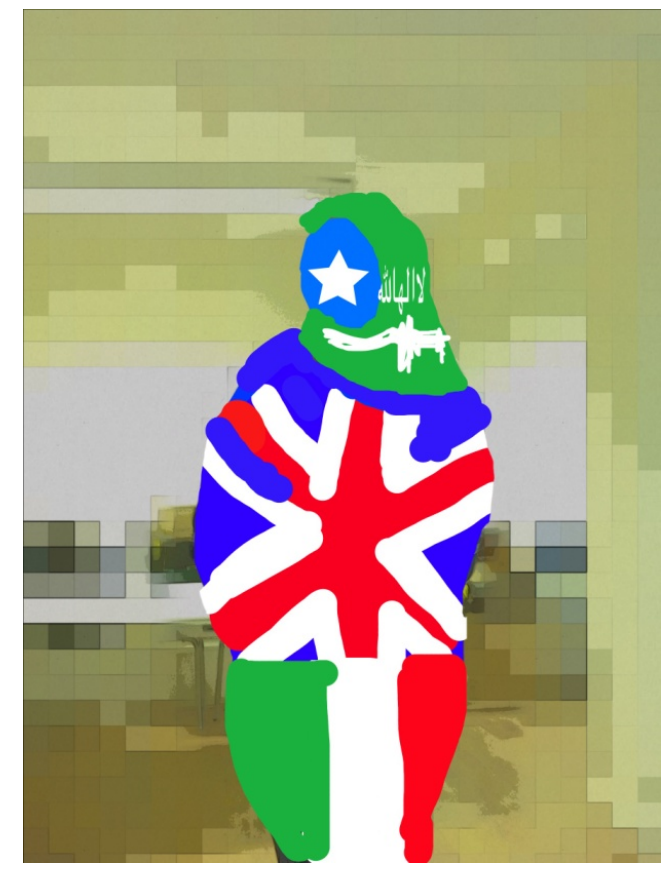

Figure 6

Amina, aged 16

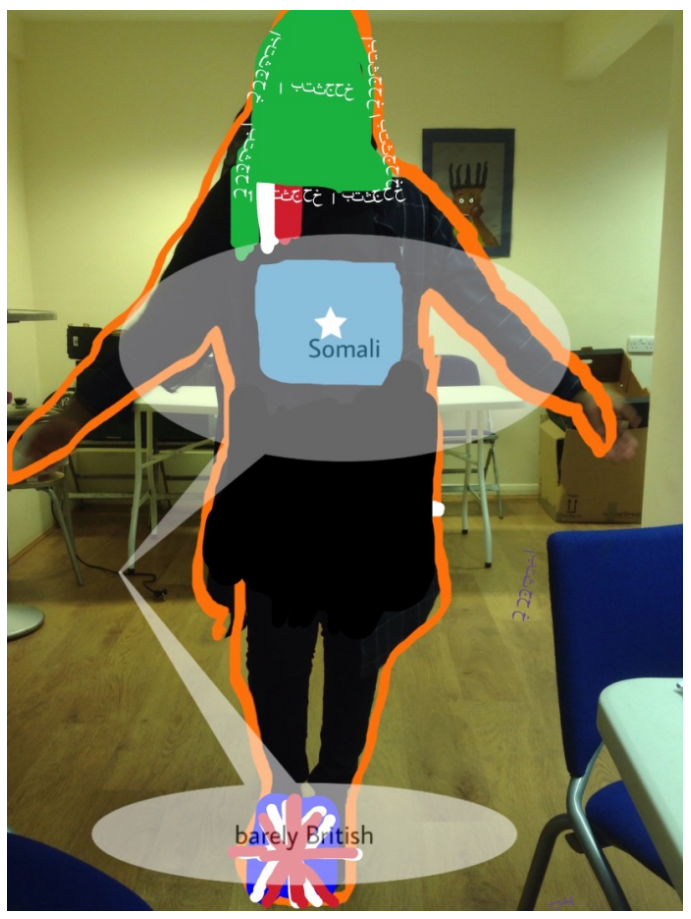

Figure 7

Robert, aged 16: J'aime ma pais

(C) Ruth Evans, 26/6/19. Please cite as Evans, R. (in press) Picturing translocal youth: self-portraits of young Syrian refugees and young people of diverse African heritages in South-East England, Population, Space \& Place. 


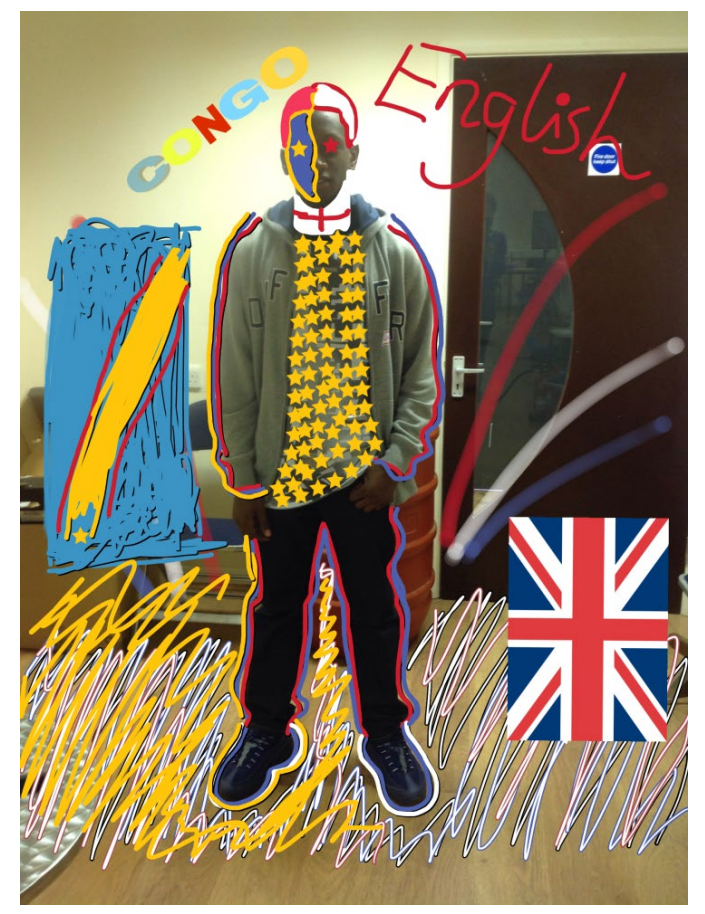

Figure 8

Lilly, aged 17: J'aime ma famille

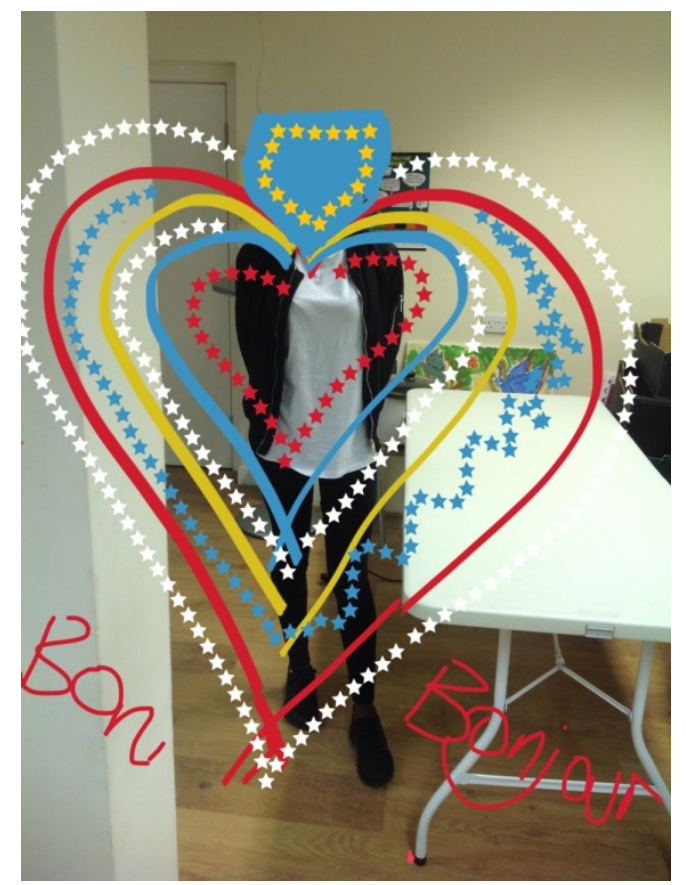

Figure 9

Hope, aged 16: Growth within existence

(C) Ruth Evans, 26/6/19. Please cite as Evans, R. (in press) Picturing translocal youth: self-portraits of young Syrian refugees and young people of diverse African heritages in South-East England, Population, Space \& Place. 


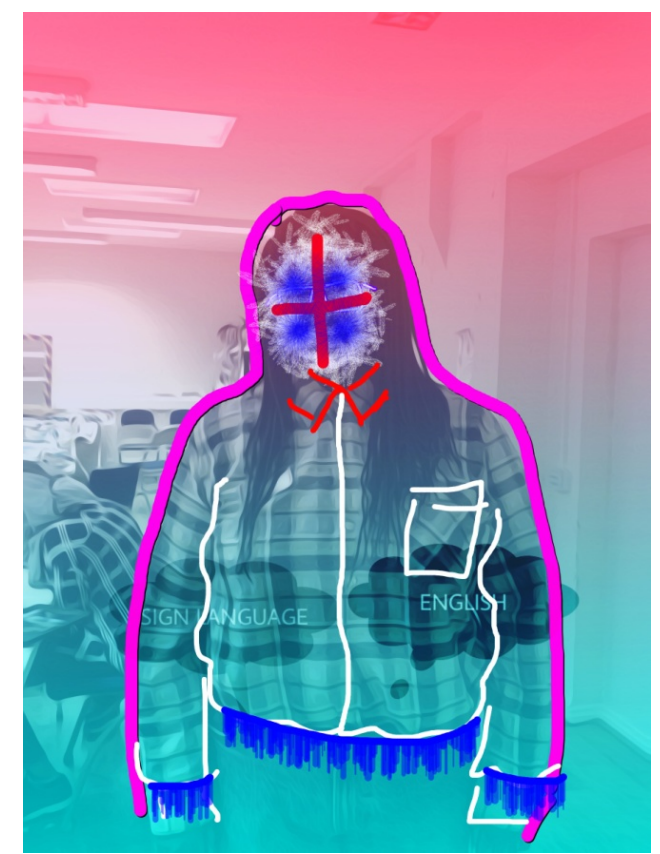

Figure 10

London is diverse, no-one is the same!

World map of translocal emotional connections co-produced with young people of African heritage in South London.

(C) Ruth Evans, 26/6/19. Please cite as Evans, R. (in press) Picturing translocal youth: self-portraits of young Syrian refugees and young people of diverse African heritages in South-East England, Population, Space \& Place. 


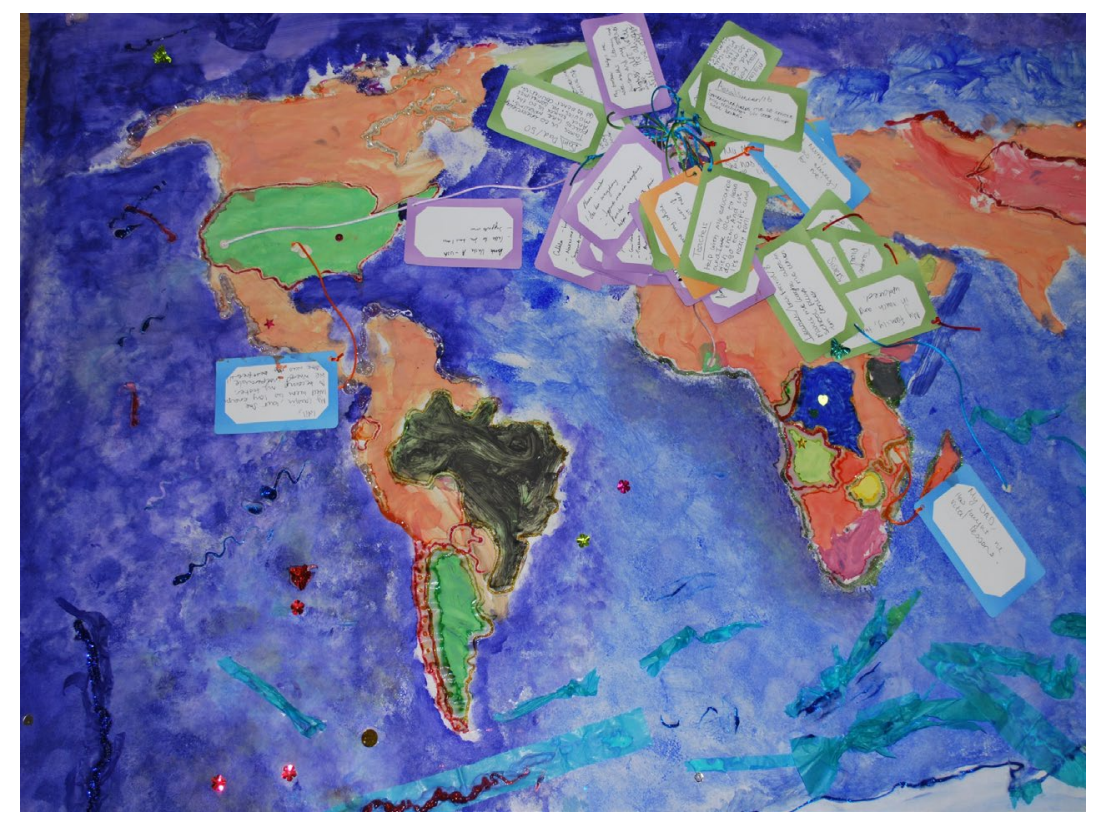

Figure 11: Close up of cards about young people's relationships on map of translocal emotional connections.

Amina: My cousin, but she lived with us long enough to become my sister. We were inseparable, she was my best friend! (thread linking London and US)

Hope: Aunt - Ghana. Helps guide me. Calls to see how I am. (thread linking London and Ghana)

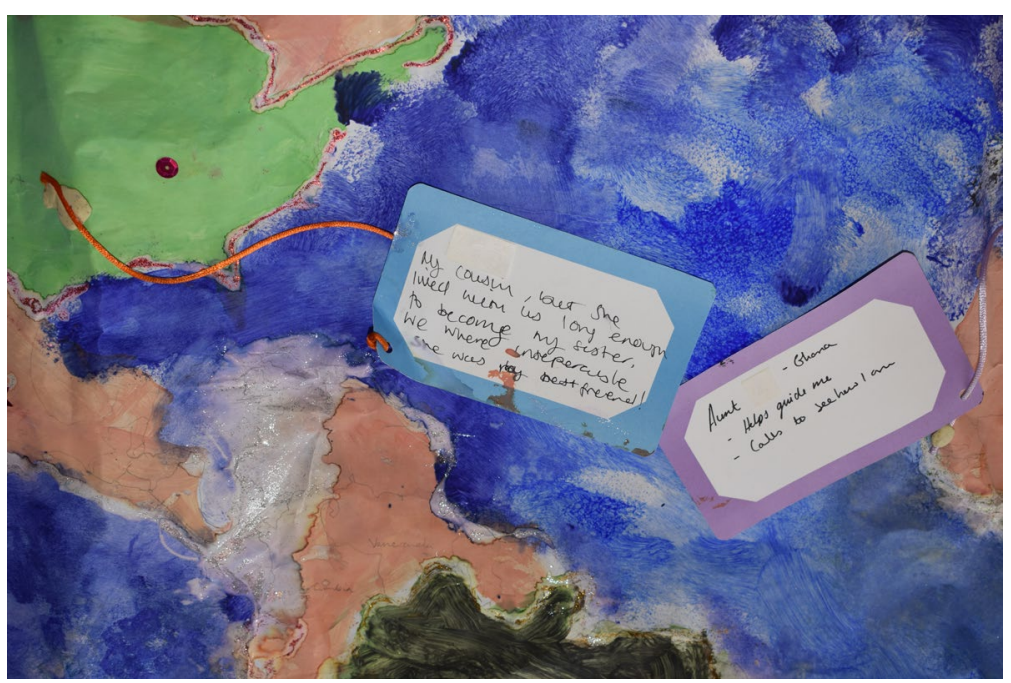

Figure 12: Close up of cards about young people's relationships on map of translocal emotional connections.

Sarah: My family, they keep in touch and keep us updated

Brothers, taught me how to play football and play video games Syrian refugees and young people of diverse African heritages in South-East England, Population, Space \& Place. 
I care for everyone by doing them favours and giving them advice whenever its needed

Sisters always give me good advice and buy me things

Dad cares for me and taught me many life lessons

My mum, she has cared for me my whole life and provides for me (linked to London, not in photo)

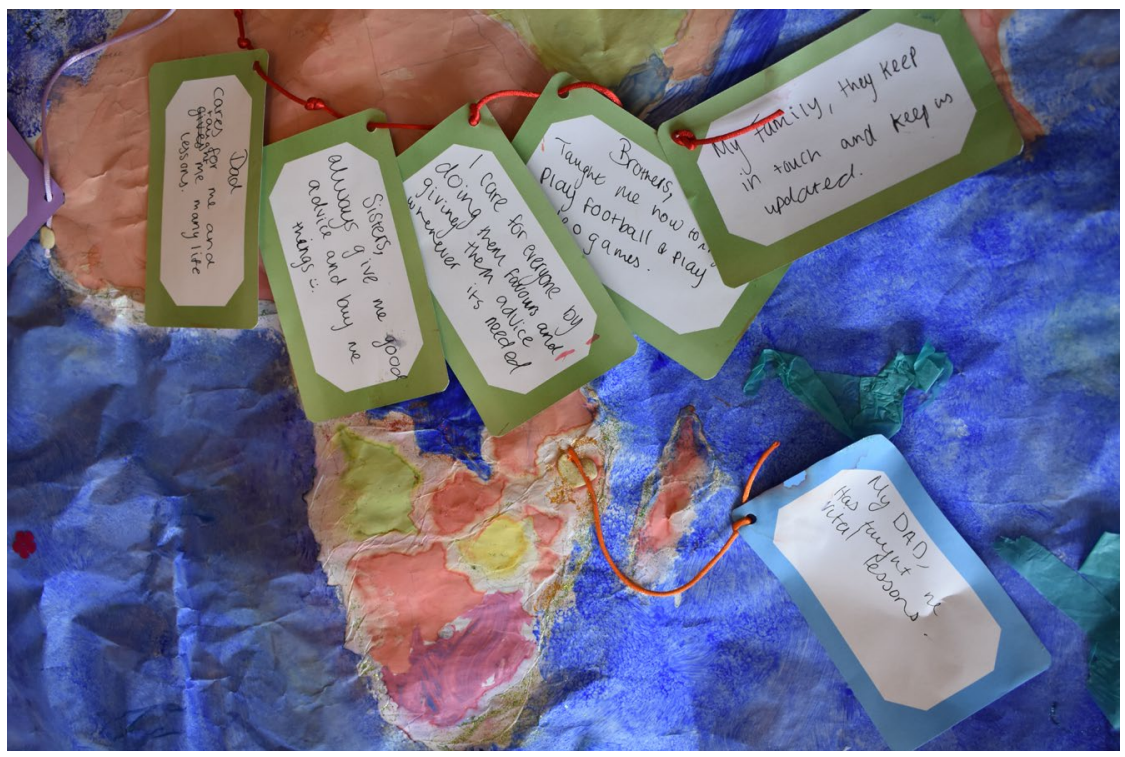

